\title{
Ekspektasi Kinerja Pembelajaran Online di Perguruan Tinggi Jakarta
}

\author{
William Surjadinata \\ Universitas Bina Nusantara, Jakarta, Indonesia \\ Diterima 19 Mei 2014 \\ Disetujui 12 Juni 2014
}

\begin{abstract}
This research calculates performance expectation of online learning system in Jakarta Undergraduate Universities. The main goal of the research is to calculate the difference of online learning system performance expectation between non experienced students and lecturers compared to the experienced students and lecturers. Data is gathered by using random sampling method, questionnaire, and analyzed in experimental research. Result of analysis shows that there is no significant difference of online learning system performance expectation between experienced and inexperienced users. It is can be concluded that online learning system still cannot be able to give a good performance expectation to users in Jakarta Undergraduate Universities. Furthermore education institution should make a better plan and evaluation to their online learning system.
\end{abstract} Learning

Index Terms - Expectation, Online, Performance,

\section{Pendahuluan}

Saat ini, teknologi informasi terus dikembangkan untuk mendukung seluruh proses dalam organisasi. Teknologi Informasi juga dapat diimplementasikan pada dunia pendidikan. Salah satu teknologi informasi yang saat ini mulai banyak digunakan pada perguruan tinggi adalah sistem pembelajaran online.

Beberapa peneliti seperti Anderson [1], Chua [2] dan Walters [3] yang telah mempelajari bagaimana sistem pembelajaran online dapat memberikan berbagai keuntungan bagi institusi pendidikan dalam hal berkomunikasi dengan para siswa, terutama pada institusi pendidikan yang jumlah mahasiswanya semakin banyak. Sistem ini dipercaya dapat membantu institusi pendidikan menjangkau lebih banyak siswa. Garison [4] menjelaskan bahwa dengan sistem pembelajaran online, siswa tidak perlu hadir dalam kelas untuk proses belajar mengajar tatap muka oleh pengajar. Sebagian besar proses belajar dan mengajar dilakukan melalui internet. Sistem dapat membantu pengajar mengkomunikasikan, membagi, dan mendiskusikan berbagai hal dengan para siswa dimanapun dan kapanpun. Materi pengajaranpun dapat dibuat menjadi lebih menarik dengan video, suara, dan berbagai informasi dari internet.

Namun, diluar keuntungan dan kelebihan yang dimiliki oleh sistem pembelajaran online tersebut, ada sebuah pertanyaan penting mengenai ekspektasi kinerja dari sistem tersebut bagi pengguna sistem pembelajaran online. Dapatkah sistem pembelajaran online memberikan ekspektasi kinerja yang baik bagi siswa maupun pengajar yang telah menggunakannya? Dikatakan baik tentunya apabila dibandingkan dengan sistem belajar konvensional. Dengan sistem pembelajaran online, pengajar tidak dapat mengetahui apa yang sedang dilakukan para siswa selama proses belajar. Mereka juga tidak dapat memastikan dengan mudah apakah siswa sudah mengerti materi yang telah diajarkan dengan baik. Disisi lain, banyak siswa yang juga mengatakan bahwa tidak mungkin dapat mengerti sebuah materi dengan baik tanpa pengajaran tatap muka. Hal-hal ini dapat membuat ekspektasi kinerja yang buruk pada sistem pembelajaran online apabila dibandingkan dengan sistem pembelajaran konvensional.

Penelitian ini berfokus pada ekspektasi kinerja, bukan pada kinerja dari sistem pembelajaran tersebut. Hal ini disebabkan kinerja dari sebuah sistem pembelajaran sangat dipengaruhi oleh berbagai faktor seperti sarana dan prasarana, lingkungan, sifat dan kualitas pengajar, dan lainnya. Sehingga kinerja dari sebuah sistem pembelajaran sulit untuk diukur karena setiap kelompok yang diukur akan menjadi tidak sepadan untuk dapat dibandingkan akibat dari banyaknya faktor yang mempengaruhi. Sedangkan ekspektasi kinerja lebih sepadan untuk diperbandingkan selama kedua kelompok yang dibandingkan sepadan atau homogen. Pertimbangan ini juga diperkuat oleh penelitian Venkatesh [7] dan Min Gong [5], dimana ekspektasi kinerja adalah salah satu hal yang mendorong seseorang untuk menggunakan sebuah sistem.

Hipotesis yang digunakan dalam penelitian ini adalah sistem pembelajaran online memiliki ekspektasi kinerja yang sama sebelum pengguna menggunakan sistem pembelajaran online dan setelah menggunakan 
sistem pembelajaran online. Pengguna yang dimaksud adalah mahasiswa dan dosen. Hipotesis ini mendukung pendapat bahwa sistem pembelajaran online memiliki ekspektasi kinerja yang tidak lebih baik dibanding sistem pembelajaran tatap muka. Ekspektasi kinerja mahasiswa dan dosen terhadap pembelajaran online adalah dependent variable yang dihitung dalam penelitian ini. Sedangkan sistem pembelajaran online adalah independent variable.

Formula yang digunakan untuk ekspektasi kinerja mahasiswa adalah sebagai berikut:

- $\mathrm{H} 0: \mu 1=\mu 2$

- $\mathrm{H} 1: \mu 1 \neq \mu 2$

Dimana $\mu 1$ adalah ekspektasi kinerja mahasiswa sebelum mengunakan sistem dan $\mu 2$ adalah eskpektasi kinerja mahasiswa setelah menggunakan sistem.

Formula yang digunakan untuk ekspektasi kinerja dosen adalah sebagai berikut:

- $\mathrm{H} 0: \mu 3=\mu 4$

- $\mathrm{H} 1: \mu 3 \neq \mu 4$

Dimana $\mu 3$ adalah ekspektasi kinerja dosen sebelum mengunakan sistem dan $\mu 4$ adalah eskpektasi kinerja dosen setelah menggunakan sistem.

Dikarenakan terbatasnya waktu, maka tidak mungkin untuk menunggu mahasiswa dan dosen yang belum berpengalaman menggunakan sistem pembelajaran online sampai mereka berpengalaman untuk dihitung perbedaan ekspektasi kinerja mereka sebelum dan sesudah berpengalaman. Maka, tidak mungkin mengukur perbedaan ekspektasi kinerja dari sekelompok sampel mahasiswa dan dosen yang sama untuk yang belum berpengalaman dan sudah berpengalaman. Oleh karena itu, maka diambil empat kelompok sampel, yaitu mahasiswa yang belum berpengalaman, mahasiswa yang sudah berpengalaman, dosen yang belum berpengalaman, dan dosen yang sudah berpengalaman menggunakan sistem pembelajaran online. Kemudian ekspektasi kinerja mahasiswa yang belum berpengalaman dibandingkan dengan mahasiswa yang sudah berpengalaman, begitupula ekspektasi kinerja dosen yang belum berpengalaman dibandingkan dengan dosen yang sudah berpengalaman.

Tujuan dari penelitian ini adalah untuk mempelajari ekspektasi kinerja sistem pembelajaran online di perguruan tinggi Jakarta, dan melakukan penelitian serta membuktikan dengan pengujian statistik mengenai perbedaan ekspektasi kinerja sistem pembelajaran online antara pengguna yang belum berpengalaman dan yang sudah berpengalaman menggunakan sistem tersebut. Sedangkan manfaat dari penelitian ini adalah agar perguruan tinggi dapat mengetahui ekspektasi kinerja pengguna terhadap sistem pembelajaran online sehingga dapat membuat perencanaan dan sistem pembelajaran yang lebih baik lagi dalam pengembangan sistem pembelajaran online mereka. Selain itu, penelitian ini dapat digunakan sebagai dasar untuk penelitian selanjutnya mengenai ekspektasi kinerja sistem pembelajaran online di Indonesia.

\section{Metode Penelitian}

\section{A. Kerangka Pikir Metode Penelitian}

Metode penelitian yang digunakan pada penelitian ini adalah penelitian eskperimental dan merupakan penelitian kuantitatif. Penelitian dimulai dengan membuat kuisioner. Proses utama dari penelitian ini adalah melakukan pengumpulan populasi dan sampel yang menggunakan random sampling, kemudian melakukan pengujian awal yang bertujuan untuk menguji homogenitas sampel dan normalitas dari hasil kuisioner yang telah dibuat, pengenalan akan sistem pembelajaran online untuk menyamakan definisi sistem pembelajaran online antar seluruh peserta pengujian, dan pengujian akhir.

Pertanyaan kuisioner didasarkan pada model UTAUT yang dikembangkan oleh Venkatesh [7]. Venkatesh mempelajari bahwa terdapat empat ekspektasi yang dapat mempengaruhi keinginan atau perilaku seseorang untuk menggunakan sebuah produk atau jasa. Keempat ekspektasi itu adalah ekspektasi kinerja, ekspektasi usaha, ekspektasi pengaruh sosial, dan ekspektasi kondisi fasilitas dari pengguna. King [4] dan Shepers [6] menguatkan pernyataan tersebut, bahwa sehebat apapun sebuah produk, namun jika para pengguna mempunyai pola pikir bahwa sistem baru tidak akan berguna, atau sulit dipelajari, atau tidak ada pengaruh sosial, atau tidak ada kondisi dan fasilitas yang mendukung, maka produk tersebut tidak akan mencapai tujuannya karena tidak ada perilaku atau keinginan yang kuat untuk digunakan oleh para pengguna.

Penelitian ini berfokus pada ekspektasi kinerja dari sistem pembelajaran online. Ekspektasi usaha tidak menjadi fokus karena setiap peserta kuisioner akan dipastikan homogen, yaitu merupakan orang-orang yang memiliki pengetahuan dan terbiasa menggunakan internet dalam kehidupan mereka sehari-hari. Sehingga kelompok sampel yang belum berpengalaman menggunakan sistem memiliki ciri-ciri yang sama dengan sampel yang sudah menggunakan sistem pembelajaran online. Mereka tidak akan memiliki ekspektasi yang buruk terhadap usaha yang mereka 
perlukan untuk menggunakan sistem pembelajaran online. Lebih lanjut, kondisi sosial di Jakarta tidak cocok untuk menciptakan pengaruh kepada seseorang untuk menggunakan sistem pembelajaran online. Sistem pembelajaran tatap muka masih merupakan sistem yang diterima dan dipercaya oleh sebagian besar penduduk Jakarta. Pilihan sistem pembelajaran setiap orang yang lulus dari sekolah menengah atas biasanya akan selalu pada sistem pembelajaran tatap muka. Mereka tidak akan mempertimbangkan sistem pembelajaran online jika tidak ada kondisi yang memaksa mereka untuk memilih sistem online, misalnya apabila siswa tersebut harus kuliah sambil bekerja. Kondisi fasilitas juga tidak akan mempengaruhi keinginan untuk menggunakan sistem pembelajaran online. Setiap perguruan tinggi yang menyediakan kelas pembelajaran online akan memastikan tersedianya fasilitas untuk sistem pembelajaran tersebut baik dari sisi mahasiswa, dosen, maupun di kampus. Walaupun pernyataan-pernyataan ini merupakan common belief atau pernyataan yang diterima secara umum, tentu saja setiap pernyataan tersebut dapat dibuktikan lebih lanjut melalui penelitian dan perhitungan secara statistik.

Dari ekspektasi kinerja yang dijabarkan Venkatesh [7], terdapat beberapa indikator yang digunakan untuk mengukur ekspektasi kinerja. Variabel, parameter, dan skala ditunjukan oleh table berikut.

Tabel 1: Variabel, Parameter, Indikator, dan skala

\begin{tabular}{|c|c|c|c|}
\hline Variabel & Parameter & Indikator & Skala \\
\hline $\begin{array}{l}\text { Ekspektasi } \\
\text { Kinerja } \\
\text { pada } \\
\text { Mahasiswa }\end{array}$ & $\begin{array}{c}\text { Ekspektasi } \\
\text { Kinerja }\end{array}$ & $\begin{array}{l}\text { 1. Kinerja } \\
\text { belajar } \\
\text { 2. Waktu yang } \\
\text { dibutuhkan } \\
\text { untuk belajar } \\
\text { 3. Kemudahan } \\
\text { Belajar }\end{array}$ & Ordinal \\
\hline $\begin{array}{c}\text { Ekspektasi } \\
\text { Kinerja } \\
\text { pada } \\
\text { Dosen }\end{array}$ & $\begin{array}{c}\text { Ekspektasi } \\
\text { Kinerja }\end{array}$ & $\begin{array}{l}\text { 1. Kinerja } \\
\text { Mengajar } \\
\text { 2. Waktu yang } \\
\text { dibutuhkan } \\
\text { untuk mengajar } \\
\text { 3. Kemudahan } \\
\text { mengajar }\end{array}$ & Ordinal \\
\hline
\end{tabular}

Tujuan dari pengujian awal adalah untuk memastikan homogenitas dan normalitas dari sampel. Dikarenakan sampel untuk yang belum berpengalaman berbeda dengan yang sudah berpengalaman, maka kedua sampel harus bersifat homogen. Kedua sampel tersebut harus memenuhi ciri-ciri yang sama sebagai pengguna potensial dari sistem pembelajaran online. Selain itu, semua sampel harus dites agar hasil pengujian menunjukan hasil yang normal. Kedua hal ini merupakan syarat agar hasil perhitungan T-Test menjadi valid.

Untuk menghitung homogenitas diantara sampel belum berpengalaman dan sudah berpengalaman, pada pengujian awal juga diberikan pertanyaanpertanyaan demografis. Seperti yang sudah disebutkan sebelumnya, dikarenakan keterbatasan waktu, tidak mungkin untuk membandingkan perbedaan ekspektasi kinerja dari sampel mahasiswa dan dosen yang sama. Karena hal tersebut membuat harus menunggu sampel yang belum berpengalaman melewati satu periode perkuliahan metode online sebelum mereka dapat diukur kembali. Maka penelitian ini mengumpulkan dua kelompok yang berbeda dari masing-masing mahasiswa dan dosen, yaitu kelompok yang belum berpengalaman dan kelompok yang berpengalaman menggunakan sistem pembelajaran online. Oleh karena itu, maka kelompok sampel yang belum berpengalaman harus homogen dengan kelompok sampel yang sudah berpengalaman. Artinya, mereka semua harus memiliki kapabilitas yang sama dalam hal menggunakan sistem pembelajaran online. Tidak ada kriteria khusus mengenai orang-orang yang memiliki kapabilitas untuk menggunakan sistem pembelajaran online. Oleh karena itu penelitian ini berusaha semaksimal mungkin menentukan kriteria-kriteria orang-orang yang memiliki kapabilitas dalam menggunakan sistem pembelajaran online. Mereka akan ditanyakan mengenai jenis kelamin, umur, kondisi finansial, serta pengalaman menggunakan komputer dan internet. Jenis kelamin dan umur ditanyakan berdasarkan penelitian Venkatesh yang menyebutkan bahwa jenis kelamin dan umur ikut menentukan ekspektasi kinerja setiap orang terhadap sebuah sistem. Selain itu, pengguna sistem pembelajaran online dipercaya memiliki kondisi finansial, pengalaman komputer dan internet yang spesifik. Apabila demografi dari kelompok yang belum berpengalaman homogen dengan kelompok yang sudah berpengalaman, maka dapat diterima bahwa penelitian ini melakukan perbandingan data yang valid dan sesuai. Berikut ini adalah pertanyaan demografis yang akan ditanyakan.

Untuk menghitung normalitas dari responden, semua sampel akan ditanyakan mengenai ekspektasi kinerja sistem pembelajaran konvensional. Mereka belum ditanyakan mengenai sistem pembelajaran online karena kelompok yang belum berpengalaman kemungkinan tidak memiliki pengetahuan yang memadai akan sistem pembelajaran online. Selain itu, kemungkinan besar pemahaman mereka akan sistem pembelajaran online masih berbeda-beda sehingga akan membuat hasil perhitungan menjadi tidak valid. 


\section{Kuisioner untuk Pengujian Akhir}

Kuisioner untuk pengujian akhir digunakan untuk menghitung perbedaan ekspektasi kinerja sistem pembelajaran online antara kelompok yang belum berpengalaman dan yang sudah berpengalaman menggunakan sistem pembelajaran online. Setelah melalui tahap proses pengenalan sistem pembelajaran online (online learning experience), diharapkan seluruh peserta sudah memiliki pemahaman yang sama atas sistem pembelajaran online sehingga hasil jawaban mereka merupakan hasil yang dapat diperbandingkan. Pada dasarnya pertanyaannya sama dengan pengujian awal, hanya kali ini yang ditanyakan adalah sistem pembelajaran online.

Pertanyaan-pertanyaan kuisioner ini diambil dari pertanyaan yang digunakan pada UTAUT yang dikembangkan oleh Venkatesh [7]. Beliau pada penelitiannya menjabarkan pertanyaan-pertanyaan yang digunakan untuk mengukur ekspektasi kinerja dari sebuah sistem. Seperti yang sudah disebutkan sebelumnya, penelitian ini mengukur ekspektasi kinerja, bukan kinerja dari sistem pembelajaran online. Sebab kinerja dari sebuah sistem pembelajaran sangat dipengaruhi oleh berbagai faktor seperti karakteristik dosen, lama waktu perkuliahan, jenis mata kuliah, kemampuan mahasiswa, dan lainnya. Oleh karena itu membandingkan kinerja dari dua buah jenis sistem pembelajaran tidak akan dapat sepadan untuk diperbandingkan. Bahkan ketika kelompok mahasiswa diuji menjalani mata kuliah yang sama dengan dosen yang sama, mereka akan lebih menguasai mata kuliah tersebut pada kedua kalinya sehingga menjadi tidak sepadan untuk diperbandingkan. Namun ekspektasi kinerja yang dimiliki setiap orang dapat lebih sepadan sebab persepsi yang dibentuk dari sebuah sistem tidak dipengaruhi oleh hal-hal yang disebutkan sebelumnya.

Berikut ini adalah pertanyaan kuisioner untuk mahasiswa:

1. Menggunakan sistem pembelajaran online akan membantu saya menyelesaikan semua tugas dengan lebih cepat dibanding dengan sistem tatap muka

2. Menggunakan sistem pembelajaran online mengurangi waktu yang diperlukan untuk mempelajari dan mengerti materi pelajaran dibanding dengan sistem tatap muka

3. Menggunakan sistem pembelajaran online akan meningkatkan hasil dari belajar saya dengan usaha yang sama apabila menggunakan sistem belajar tatap muka

4. Menggunakan sistem pembelajaran online membuat saya dapat meningkatkan kualitas dari pengetahuan saya

5. Menggunakan sistem pembelajaran online membuat saya meningkatkan kualitas dari hasil ujian dan tugas

6. Menggunakan sistem pembelajaran online mengurangi usaha yang saya perlukan untuk menemukan materi utama dan tambahan dari berbagai sumber

7. Menggunakan sistem pembelajaran online mengurangi usaha saya untuk mempelajari materi

8. Menggunakan sistem pembelajaran online membuat lebih mudah untuk mempelajari materi dibanding sistem tatap muka

Berikut ini merupakan pertanyaan kuisioner untuk dosen:

1. Menggunakan sistem pembelajaran online membantu saya menyelesaikan tugas pengajaran lebih cepat dibandingkan sistem pembelajaran tatap muka

2. Menggunakan sistem pembelajaran online mengurangi waktu yang saya butuhkan untuk membuat mahasiswa mengerti materi dibandingkan sistem pembelajaran tatap muka.

3. Menggunakan sistem pembelajaran online dapat meningkatkan hasil dari pengajaran saya dengan usaha yang sama dengan menggunakan sistem pembelajaran tatap muka.

4. Menggunakan sistem pembelajaran online meningkatkan kualitas pengetahuan mahasiswa

5. Menggunakan sistem pembelajaran online meningkatkan kualitas dari hasil ujian dan tugas mahasiswa.

6. Menggunakan sistem pembelajaran online mengurangi usaha yang saya butuhkan untuk mencari materi dan tambahan materi dari berbagai sumber

7. Menggunaka sistem pembelajaran online mengurangi usaha yang saya butuhkan dalam persiapan dan proses mengajar.

8. Menggunakan sistem pembelajaran online memudahkan saya untuk mengajar

\section{$36 \quad$ ULTIMA InfoSys, Vol. V, No. 1 | Juni 2014}




\section{Pengumpulan Populasi dan Sampel}

Populasi dari penelitian ini adalah mahasiswa dan dosen perguruan tinggi Jakarta yang belum berpengalaman maupun yang sudah berpengalaman menggunakan sistem pembelajaran online. Kemudian, untuk memastikan tingkat homogen antar seluruh sampel, maka populasi diperkecil kembali dimana mahasiswa dan dosen tersebut harus memiliki kapabilitas untuk menggunakan sistem pembelajaran online.

Pada dasarnya, metode pengumpulan sampel menggunakan metode random sampling atau pengumpulan sampel acak. Berdasarkan data dari kementrian pendidikan nasional Indonesia, ada 425 universitas di Jakarta. Sayangnya, tidak ada informasi yang lengkap mengenai jumlah mahasiswa dan dosen aktif di setiap universitas. Untuk mendapatkan informasi tersebut, diperlukan surat permohonan resmi kepada setiap universitas. Dikarenakan terbatasnya waktu, maka hal tersebut tidak mungkin dilakukan. Maka, jumlah populasi yang pasti tidak diketahui. Oleh karena itu, metode sampel acak dimulai dengan pemilihan universitas secara acak. Seluruh nama universitas dan perguruan tinggi didaftarkan dalam urutan yang acak, kemudian dipilihlah universitas dengan cara memilih nama setiap urutan kesepuluh, keduapuluh, dan seterusnya hingga didapatkan 42 nama universitas dan perguruan tinggi. Kuisioner disebarkan kepada sampel mahasiswa dari 42 universitas tersebut secara acak. Sehingga tidak seluruh mahasiswa dari universitas-universitas tersebut yang akan menjadi responden penelitian ini. Penyebaran kuisionerpun dilakukan tidak secara resmi pada perkuliahan, namun secara tidak resmi di tempat-tempat umum maupun media sosial. Mahasiswa yang akhirnya dihubungi untuk menjadi responden adalah mahasiswa yang memiliki kapabilitas standar untuk dapat menggunakan sistem pembelajaran online, yaitu memiliki komputer dan terbiasa dengan internet dalam kehidupan seharihari.

Proses kuisioner dilakukan dengan fasilitas internet dan manual. Tentu saja proses ini dapat menggapai sampel yang bukan merupakan mahasiswa atau dosen dari kedelapan perguruan tinggi tersebut. Namun selama masih merupakan mahasiswa atau dosen aktif dari 42 perguruan tinggi yang telah dipilih, serta memenuhi syarat kapabilitas dalam menggunakan sistem pembelajaran online, maka mereka akan dianggap sebagai responden valid.

\section{Hasil dan Pembahasan}

\section{A. Hasil Uji Homogenitas dari Pengujian Awal}

Untuk memastikan bahwa kelompok sampel yang belum berpengalaman homogen dengan kelompok sampel yang sudah berpengalaman, maka perlu dilakukan tes homogenitas. Apabila kedua kelompok tersebut saling homogen, artinya mereka merupakan orang-orang yang sama-sama memiliki kapabilitas untuk menggunakan sistem pembelajaran online. Hal ini tentu saja akan membuat hasil ekspektasi kinerja mereka dapat diperbandingkan. Hasil uji homogenitas dilakukan berdasarkan hasil dari jawaban pertanyaan demografis. Berikut ini adalah hasil uji homogenitas untuk mahasiswa maupun dosen.

Tabel 2: Hasil Uji Homogenitas Varian pada Mahasiswa.

\begin{tabular}{|l|c|c|c|c|}
\hline & $\begin{array}{l}\text { Levene } \\
\text { Statistic }\end{array}$ & Df1 & Df2 & Sig. \\
\hline $\begin{array}{l}\text { Based on mean } \\
\text { Based on }\end{array}$ & .260 & 1 & 1769 & .610 \\
$\begin{array}{l}\text { median } \\
\text { Based on } \\
\begin{array}{l}\text { median and } \\
\text { with adjusted d } \\
\text { Based on } \\
\text { trimmed mean }\end{array}\end{array}$ & .635 & 1 & 1769 & .426 \\
\hline
\end{tabular}

Tabel 3: Hasil Uji Homogenitas Varian pada Dosen

\begin{tabular}{|l|c|c|c|c|}
\hline & $\begin{array}{l}\text { Levene } \\
\text { Statistic }\end{array}$ & Df1 & Df2 & Sig. \\
\hline $\begin{array}{l}\text { Based on mean } \\
\text { Based on }\end{array}$ & 2.436 & 1 & 427 & .119 \\
$\begin{array}{l}\text { median on } \\
\text { Based } \\
\begin{array}{l}\text { median and with } \\
\text { adjusted df } \\
\text { Based on } \\
\text { trimmed mean }\end{array}\end{array}$ & 1.184 & 1 & 416.355 & .277 \\
\hline
\end{tabular}

Seluruh sampel mahasiswa menunjukan signifikansi sebesar 0,610. Sedangkan seluruh sampel dosen menunjukan signifikansi sebesar 0,119. Karena kedua signifikansi berdasarkan rata-rata tersebut bernilai diatas 0,05 , maka baik sampel mahasiswa maupun dosen dapat dipastikan homogen dan memiliki karakteristik yang sama dalam hal pengguna potensial atau memiliki kapabilitas dalam menggunakan sistem pembelajaran online.

\section{B. Hasil Uji Normalitas dari Pengujian Awal}

Selain harus homogen, seluruh sampel yang telah dikumpulkan juga harus dapat merepresentasikan populasi. Untuk dapat meyakinkan bahwa seluruh sampel telah mewakili populasi, maka seluruh kelompok sampel diuji normalitasnya. Pertanyaan dalam kuisioner pengujian awal ini juga diambil dari pertanyaan UTAUT. Namun yang ditanyakan adalah 
ekspektasi mereka mengenai sistem pembelajaran tatap muka. Tujuannya hanya untuk mengukur normalitas dari jawaban mereka. Dimana jawaban atas kuisioner pengujian awal mereka harus memiliki nilai yang normal.

Tabel 4: Hasil Uji Normalitas Terhadap Mahasiswa

\begin{tabular}{|c|c|c|c|c|c|c|}
\hline \multirow{2}{*}{} & \multicolumn{3}{|c|}{$\begin{array}{c}\text { Kolmogorov- } \\
\text { Smirnov }\end{array}$} & \multicolumn{3}{c|}{ Shapiro-Wilk } \\
\cline { 2 - 7 } & Statistic & Df & Sig. & Statistic & Df & Sig. \\
\hline Variable & .166 & 1005 & $\mathbf{. 0 0 7}$ & .936 & 1005 & .111 \\
\hline
\end{tabular}

Tabel 5: Hasil Uji Normalitas Terhadap Dosen

\begin{tabular}{|c|c|c|c|c|c|c|}
\hline \multirow{2}{*}{} & \multicolumn{3}{|c|}{$\begin{array}{c}\text { Kolmogorov- } \\
\text { Smirnov }\end{array}$} & \multicolumn{3}{c|}{ Shapiro-Wilk } \\
\cline { 2 - 7 } & Statistic & Df & Sig. & Statistic & Df & Sig. \\
\hline Variable & .156 & 256 & $\mathbf{. 0 7 8}$ & .928 & 256 & .156 \\
\hline
\end{tabular}

Berdasarkan hasil tes normalitas Kogorov Smirnov dan Shapiro-Wilk, nilai signifikansi dari semua sampel menunjukan angka diatas 0.05 sehingga dapat diambil kesimpulan bahwa semua sampel bersifat normal dan dapat merepresentasikan populasi.

\section{Proses Pengenalan Sistem Pembelajaran Online}

Tahap selanjutnya dari penelitian ini adalah proses pengenalan sistem pembelajaran online (online learning experience). Tujuan dari tahap ini adalah agar seluruh responden memiliki pemahaman dan definisi yang sama pada sistem pembelajaran online yang dimaksud pada penelitian ini. Proses ini dilakukan dengan membuat kelompok-kelompok dan memilih ketua kelompok dari setiap kelompok responden. Setiap kelompok dipilih sesuai dengan komunitasnya agar memudahkan komunikasi dan penyebaran informasi. Mereka diberikan kesempatan untuk mencoba sistem pembelajaran online. Media utama yang digunakan untuk seluruh responden adalah Aplikasi Online Learning Virtual, yaitu Binus Online Learning Virtual. Agar tidak menimbulkan paham bahwa Binus Online Learning Virtual adalah sistem pembelajaran online satu-satunya atau yang paling merepresentasikan proses pembelajaran online di Jakarta, maka responden juga diberikan informasi mengenai berbagai kursuskursus online yang ada pada internet seperti openlearn dan Alison agar responden memiliki kesepahaman mengenai sistem pembelajaran online.

Matakuliah yang digunakan dalam proses pembelajaran online ini adalah kemampuan akademik. Hal ini agar mahasiswa dari jurusan apapun dapat memahami materi kuliah. Mereka akan mempelajari matakuliah ini sepenuhnya dengan menggunakan sistem online. Setiap responden harus memberikan umpan balik untuk setiap aktivitas di proses ini. Mereka diminta untuk mencoba memahami proses pembelajaran online, kemudian proses pembelajaran di dalam online, serta mempelajari media pembelajaran online lainnya. Proses ini dilakukan kurang lebih dalam rentang 1 bulan. Hal ini disebabkan karena keterbatasan waktu penelitian. Selain itu, penelitian ini tidak mengukur kinerja dari sistem pembelajaran, sehingga tidak perlu melakukan proses pembelajaran online hingga setengah atau satu semester. Seperti yang disebutkan sebelumnya, tujuan proses pengenalan ini adalah memberikan pengalaman bagi seluruh responden dan agar mereka semua memiliki definisi yang sama akan sistem pembelajaran online yang dimaksud dalam penelitian ini. Sehingga ketika mereka menjawab kuisoner akhir, jawaban mereka menjadi sepadan untuk diperbandingkan.

\section{Hasil Pengujian Akhir}

Setelah semua proses sebelumnya selesai, tahap terakhir adalah melakukan pengujian akhir. Seluruh sampel telah terbukti homogen dan normal. Mereka juga dianggap telah memiliki pemahaman yang sama akan sistem pembelajaran online. Sehingga nilai ekspektasi kinerja kelompok yang belum berpengalaman dapat dibandingkan dengan yang sudah berpengalaman. Dengan semua proses uji dan pemilihan sampel yang telah dilakukan, perbandingan kedua kelompok ini dapat dianggap sama dengan apabila pengujian dilakukan pada kelompok yang sama sebelum mereka berpengalaman dan setelah mereka berpengalaman.

Proses pengujian akhir dilakukan dengan membandingkan hasil ekspektasi kinerja sampel mahasiswa yang belum berpengalaman dengan mahasiswa yang sudah berpengalaman. Hal yang sama juga dilakukan dengan sampel dosen yang belum berpengalaman dibandingkan dengan yang sudah berpengalaman. Proses perbandingan tersebut diuji dengan menggunakan tes statistik T-Test. Berikut ini adalah hasil pengujian T-Test terhadap perbedaan ekspektasi kinerja mahasiswa terhadap sistem pembelajaran online. Grp 1 adalah kelompok mahasiswa yang belum berpengalaman sedangkan Grp 2 adalah kelompok mahasiswa yang sudah berpengalaman menggunakan sistem pembelajaran online.

\section{$38 \quad$ ULTIMA InfoSys, Vol. V, No. 1 | Juni 2014}


Tabel 6: Hasil Uji T-Test Pada Mahasiswa

\begin{tabular}{|c|c|c|c|c|c|}
\hline \multicolumn{6}{|c|}{ Paired Samples Statistics } \\
\hline & & Mean & $N$ & $\begin{array}{l}\text { Std. } \\
\text { Deviation }\end{array}$ & $\begin{array}{l}\text { Std. } \\
\text { Error } \\
\text { Mean }\end{array}$ \\
\hline \multirow{3}{*}{$\begin{array}{l}\text { Pair } \\
1\end{array}$} & & & & & \\
\hline & Grpl & 55.4098 & 610 & 17.71351 & 0.7172 \\
\hline & Grp2 & 55.4918 & 610 & 19.25234 & 0.7795 \\
\hline
\end{tabular}

\begin{tabular}{|ll|c|c|c|}
\hline \multicolumn{5}{|c|}{ Paired Samples Correlations } \\
\hline & & $N$ & Correlation & Sig. \\
\hline $\begin{array}{l}\text { Pair } \\
1\end{array}$ & Grp1 & & & \\
& Grp2 & 610 & 0.02 & 0.621 \\
\hline
\end{tabular}

\begin{tabular}{|c|c|c|c|c|c|}
\hline \multicolumn{6}{|c|}{ Paired Samples Test } \\
\hline & \multicolumn{5}{|c|}{ Paired Differences } \\
\hline & \multirow[b]{2}{*}{ Mean } & \multirow{2}{*}{$\begin{array}{c}\text { Std } \\
\text { Devia } \\
\text { tion }\end{array}$} & \multirow{2}{*}{$\begin{array}{l}\text { Std } \\
\text { Error } \\
\text { Mean }\end{array}$} & \multicolumn{2}{|c|}{$\begin{array}{c}95 \% \\
\text { Confidence } \\
\text { interval } \\
\text { of the } \\
\text { Difference }\end{array}$} \\
\hline & & & & $\begin{array}{l}\text { Low } \\
\text { er }\end{array}$ & $\begin{array}{l}U p p \\
e r\end{array}$ \\
\hline $\begin{array}{ll}\text { Pair 1 } & \text { Grp1- } \\
& \text { Grp2 }\end{array}$ & -0.82 & 26.4 & 1.07 & -2.18 & 2.02 \\
\hline
\end{tabular}

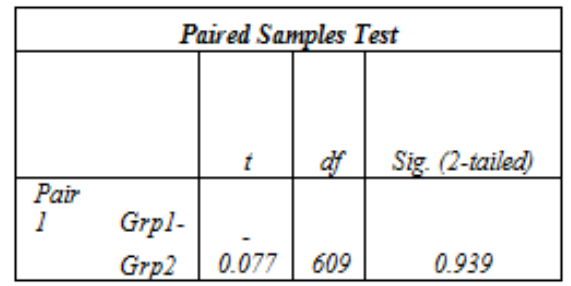

Hasil uji T-Test pada kelompok mahasiswa menunjukan signifikansi sebesar 0,939. Karena angka tersebut lebih besar dari 0,05, Maka dapat disimpulkan bahwa tidak ada perbedaan yang signifikan antara ekspektasi kinerja sistem pembelajaran online setelah mahasiswa menjadi berpengalaman dengan sistem tersebut. Hal ini menunjukan bahwa sistem tersebut tidak memberikan ekspektasi yang lebih baik dibandingkan dengan sebelum mereka menggunakan sistem pembelajaran online. Hal ini menunjukan bahwa bagi mahasiswa, sistem tersebut tidak memberikan manfaat yang lebih baik dibanding sebelum mereka menggunakannya.

Berikut ini adalah hasil pengujian T-Test terhadap perbedaan ekspektasi kinerja dosen terhadap sistem pembelajaran online. Grp 1 adalah kelompok dosen yang belum berpengalaman sedangkan Grp 2 adalah kelompok dosen yang sudah berpengalaman menggunakan sistem pembelajaran online.

\begin{tabular}{|c|c|c|c|c|c|}
\hline \multicolumn{6}{|c|}{ Paired Samples Statistics } \\
\hline & & Mean & $\mathrm{N}$ & $\begin{array}{l}\text { Std. } \\
\text { Deviation }\end{array}$ & $\begin{array}{l}\text { Std. } \\
\text { Error } \\
\text { Mean }\end{array}$ \\
\hline \multirow{3}{*}{$\begin{array}{l}\text { Pair } \\
1\end{array}$} & & & & & \\
\hline & Grp1 & 61.7586 & 145 & 16.16464 & 1.3424 \\
\hline & $\operatorname{Grp} 2$ & 64.7586 & 145 & 16.94897 & 1.40754 \\
\hline
\end{tabular}

\begin{tabular}{|ll|c|c|c|}
\hline \multicolumn{5}{|c|}{ Paired Samples Correlations } \\
\hline & & N & Correlation & Sig. \\
\hline Pair & & & & \\
1 & Grp1 & & & \\
& Grp2 & 145 & 0.28 & 0.737 \\
\hline
\end{tabular}
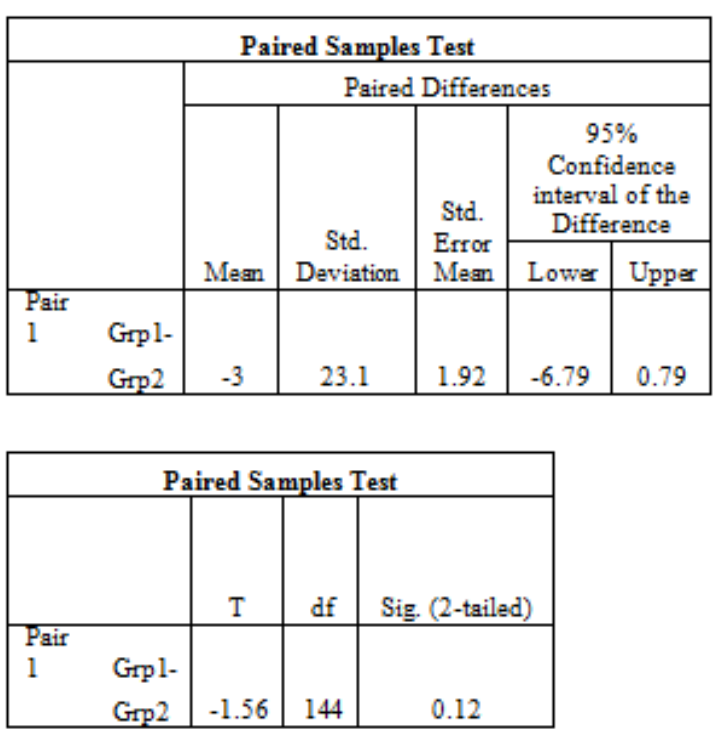

Hasil uji T-Test pada kelompok dosen menunjukan signifikansi sebesar 0,120. Karena angka tersebut lebih besar dari 0,05, Maka dapat disimpulkan bahwa tidak ada perbedaan yang signifikan antara ekspektasi kinerja sistem pembelajaran online setelah dosen menjadi berpengalaman dengan sistem tersebut. Hal ini menunjukan bahwa sistem tersebut tidak memberikan ekspektasi yang lebih baik dibandingkan dengan sebelum mereka menggunakan sistem pembelajaran online. Hal ini menunjukan bahwa bagi dosen, sistem tersebut tidak memberikan manfaat yang lebih baik dibanding sebelum mereka menggunakannya.

\section{Simpulan}

Berdasarkan hasil uji statistic T-Test baik pada kelompok mahasiswa maupun dosen, maka H0 diterima, yaitu tidak ada perbedaan signifikan antara ekspektasi kinerja yang dimiliki pengguna yang sudah berpengalaman dibandingkan dengan yang belum berpengalaman menggunakan sistem pembelajaran online. Responden yang belum berpengalaman tentunya mendasarkan pengetahuan yang mereka 
miliki akan sistem pembelajaran online dengan dibandingkan dengan sistem konvensional tatap muka yang sudah mereka kenal selama ini. Mereka akan membuat eskpektasi kinerja atas sistem tersebut. Dengan melihat bahwa ternyata setelah mereka manggunakan sistem tersebut, tidak ada perbedaan signifikan pada ekspektasi kinerja mereka, maka dapat disimpulkan bahwa sistem pembelajaran online belum dapat memberikan hasil yang lebih baik dibandingkan dengan sistem pembelajaran tatap muka.

Berdasarkan hasil tes tersebut, maka setiap institusi pendidikan yang ingin menerapkan sistem pembelajaran online, maka harus mempertimbangkan dan membuat perencanaan yang sebaik-baiknya. Mengingat bahwa mahasiswa dan dosen di Jakarta tidak memiliki ekspektasi kinerja pada sistem tersebut lebih baik dibandingkan sistem tatap muka. Mereka cenderung akan berpikir jika tidak lebih baik, mengapa harus memilih sistem yang baru. Sedangkan setiap institusi pendidikan yang telah menjalankan sistem pembelajaran online sebaiknya melakukan evaluasi dan perbaikan pada sistem pembelajaran online sehingga dapat meningkatkan ekspektasi kinerja pada sistem pembelajaran online.

Penelitian lebih lanjut dapat dilakukan untuk mengukur apakah perbedaan kota dapat mempengaruhi ekspektasi kinerja pada sistem pembelajaran online. Selain itu penelitan lebih lanjut juga dapat dilakukan untuk mengukur apakah perbedaan subjek atau materi perkuliahan dapat mempengaruhi ekspektasi kinerja pada sistem pembelajaran online.

\section{UCAPAN TERIMA Kasih}

Terima kasih diucapkan terutama kepada Tuhan Yang Maha Esa atas tuntunannya selama proses penelitian ini berlangsung. Terima kasih juga diucapkan kepada rekan-rekan dosen Universitas Bina Nusantara dan rekan dosen dari Universitas Trisakti yang telah membantu saya dalam penyusunan metode penelitian yang digunakan dalam penelitian ini. Terima kasih juga diucapkan kepada seluruh responden yang telah terlibat sepanjang penelitian ini.

\section{Daftar Pustaka}

[1] Anderson, dan Elloumi, "Theory and Practice of Online Learning," Canada, Athabasca University, 2004.

[2] Chua, "Perception of Quality in Higher Education," AUQA Occasional Publication, 2005.

[3] Garrison dan Innes, "Facilitating Cognitive Presence in Online Learning: Interaction is Not Enough,” The American Journal of Distance Education, Vol. 19 Issue 3, 2005.

[4] King dan He, "A Meta Analysis of Technology Acceptance Model," Science Direct of Information and Management Vol. 42, 2005.

[5] Min Gong, Yan Xu, dan Yuecheng Yu, "An Enhanced Technology Acceptance Model for Web-Based Learning," Journal of Information System Education Vol. 15 Issue 4, 2004.

[6] Schepers dan Wetzels, "A Meta Analysis of Technology Acceptance Model: Investigating Subjective Norm and Moderation Effects," Science Direct of Information and Management Vol. 44, 2007.

[7] Venkatesh, Morris, Gordon, dan Fred, "User Acceptance if Information Technology: Toward a Unified View," MIS Quarterly Vol. 27.

[8] Walters, Shaw, dan Cagne, "Want to Teach Online? Things You Should Know," Journal of eLearning and Online Teaching Vol.1 Issue 4, 2010.
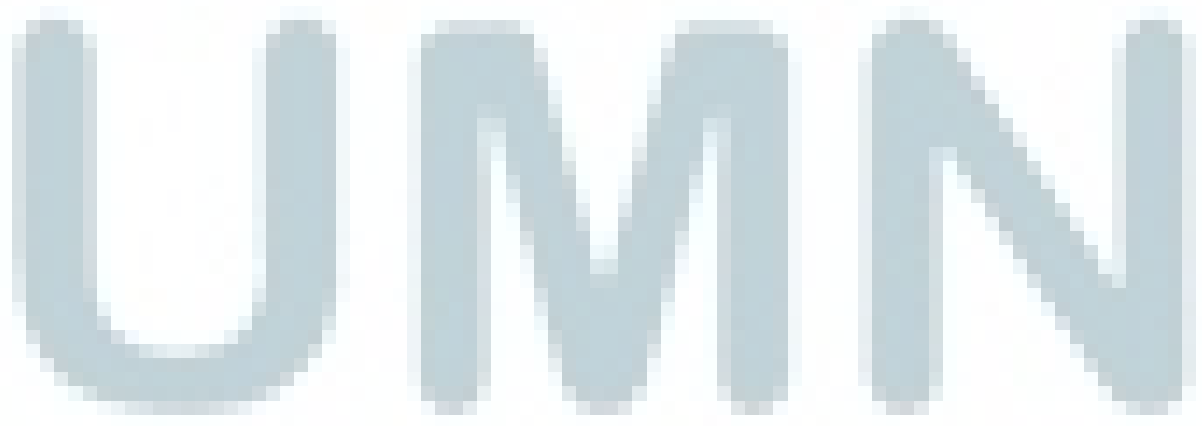

\section{$40 \quad$ ULTIMA InfoSys, Vol. V, No. 1 | Juni 2014}

